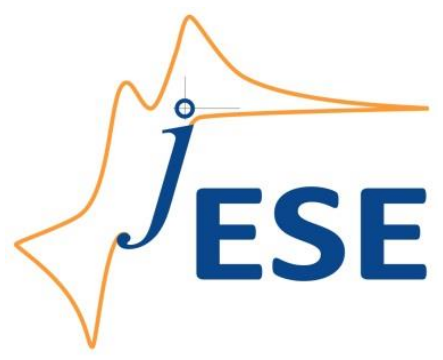

Open Access : : ISSN 1847-9286

www.jESE-online.org

Original scientific paper

\title{
Electrochemical combustion of indigo at ternary oxide coated titanium anodes
}

\author{
María I. León, Zaira G. Aguilar and José L. Nava ${ }^{\bowtie}$
}

Departamento de Ingeniería Geomática e Hidráulica, Universidad de Guanajuato, Av. Juárez 77, Zona Centro, C.P. 36000, Guanajuato, Guanajuato, Mexico

${ }^{\otimes}$ Corresponding Author: E-mail: jInm@ugto.mx; Tel.: +52-473-1020100 ext. 2289; Fax: +52-473-1020100 ext. 2209

Received: August 04, 2014; Revised: August 22, 2014; Published: December 6, 2014

\begin{abstract}
The film of iridium and tin dioxides doped with antimony $\left(\mathrm{IrO}_{2}-\mathrm{SnO}_{2}-\mathrm{Sb}_{2} \mathrm{O}_{5}\right)$ deposited on a Ti substrate (mesh) obtained by Pechini method was used for the formation of ${ }^{\circ} \mathrm{OH}$ radicals by water discharge. Detection of ${ }^{\circ} \mathrm{OH}$ radicals was followed by the use of the $N, N$-dimethyl-p-nitrosoaniline (RNO) as a spin trap. The electrode surface morphology and composition was characterized by SEM-EDS. The ternary oxide coating was used for the electrochemical combustion of indigo textile dye as a model organic compound in chloride medium. Bulk electrolyses were then carried out at different volumetric flow rates under galvanostatic conditions using a filter-press flow cell. The galvanostatic tests using $\mathrm{RNO}$ confirmed that $\mathrm{Ti} / \mathrm{IrO} \mathrm{I}_{2}-\mathrm{SnO}_{2}-\mathrm{Sb}_{2} \mathrm{O}_{5}$ favor the hydroxyl radical formation at current densities between 5 and $7 \mathrm{~mA} \mathrm{~cm}{ }^{-2}$, while at current density of $10 \mathrm{~mA} \mathrm{~cm}{ }^{-2}$ the oxygen evolution reaction occurs. The indigo was totally decolorized and mineralized via reactive oxygen species, such as $\left({ }^{\circ} \mathrm{OH}, \mathrm{H}_{2} \mathrm{O}_{2}, \mathrm{O}_{3}\right.$ and active chlorine) formed in-situ at the $\mathrm{Ti} / \mathrm{IrO}_{2}-\mathrm{SnO}_{2}-\mathrm{Sb}_{2} \mathrm{O}_{5}$ surface at volumetric flow rates between $0.1-0.4 \mathrm{~L} \mathrm{~min}^{-1}$ and at fixed current density of $7 \mathrm{~mA} \mathrm{~cm} \mathrm{~cm}^{-2}$. The mineralization of indigo carried out at $0.2 \mathrm{~L} \mathrm{~min}^{-1}$ achieved values of $100 \%$, with current efficiencies of $80 \%$ and energy consumption of $1.78 \mathrm{KWh} \mathrm{m}^{-3}$.
\end{abstract}

\section{Keywords}

Dimensionally stable anodes; electrochemical degradation of organics; Pechini method; textile effluents; indigo textile dye 


\section{Introduction}

Textile processing industries nowadays are widespread sectors in many countries. This industry is one of the most polluting industries in terms of the volume, color and complexity of its effluent discharge. Textile effluents include dyes that have a complex chemical structure, which most of the time are disposed on municipal sewers or into surface waters. Residual textile dyes tend to be transformed into toxic aromatic amines which cannot be degraded by sunlight and, once in the environment, they exhibit recalcitrant properties [1-3].

Electrochemical incineration [4-10] is a technique that has been found adequate for the treatment of colored wastewaters. It is important to point out that several color degradation studies mention systems with platinum electrodes [7] and dimensionally stable anodes (DSA) $[6,8]$, which have shown mineralization of 50-70\%. Dogan and Turkdemir [7] consider that mineralization of indigo dye on $\mathrm{Pt}$ is induced by by-products of water and chloride discharge on the platinum surface; however, the indigo achieved mineralization of $60 \%$. Similar results in the degradation of acid red 29 [11], reactive blue 19 [8], mediated by active chlorine (given by the mixture of chlorine $\left(\mathrm{Cl}_{2}\right)$, hypochlorous acid $(\mathrm{HOCl})$ and hypochlorite ion $\left.\left(\mathrm{OCl}^{-}\right)\right)$, produced on DSA lead to mineralization of $56 \%$ and $70 \%$, respectively. BDD electrodes exhibit a superior performance, since a large amount of hydroxyl radicals $\left({ }^{\circ} \mathrm{OH}\right)$ are formed by water oxidation on the BDD surface [5-6,12-13], achieving $100 \%$ efficiency in color removal and mineralization. The main problem encountered with BDD electrode is its high price limiting its industrial application.

For the above it is necessary to develop a DSA of metal oxides as an alternative to oxidize recalcitrant organic matter similar to a BDD electrode, in other words to produce DSA $\left({ }^{\circ} \mathrm{OH}\right)$ capable to oxidize recalcitrant organic matter. Comninellis and coworkers have developed a DSA electrode of $\mathrm{SnO}_{2}-\mathrm{Sb}_{2} \mathrm{O}_{5}$ with an interlayer between supports (Ti) of $\mathrm{IrO}_{2}$ by the spray pyrolysis technique, capable to produce hydroxyl radicals physisorbed on DSA (Eq. 1), by water discharge [14]. The interlayer of $\mathrm{IrO}_{2}$ improves useful life of the electrode. These authors put on evidence that the physisorbed hydroxyl radical DSA $\left({ }^{\circ} \mathrm{OH}\right)$ cause predominantly the complete combustion of organics $(R)$, Eq. (2); for example, these authors demonstrated that DSA $\left({ }^{\circ} \mathrm{OH}\right)$ reacts with p-clorophenol leading to complete combustion. On such electrode, $\mathrm{IrO}_{2}$ acts as a catalyst, $\mathrm{SnO}_{2}$ acts as a dispersing agent and $\mathrm{Sb}_{2} \mathrm{O}_{5}$ as a doping agent. Such ternary electrodes are among the best electrocatalysts for $\mathrm{O}_{2}$ evolution, being able to produce physisorbed hydroxyl radicals on their surface from water discharge. The high catalytic activity of this ternary oxide electrode has been recently reported for the electrochemical oxidation of other organic compounds $[15,16]$. Another paper by Comninellis put on evidence the convenience of using $\mathrm{Ti} / \mathrm{SnO}_{2}$ to oxidize phenol matter via ${ }^{\circ} \mathrm{OH}$ radicals adsorbed onto $\mathrm{Ti} / \mathrm{SnO}_{2}$ [17]. However, the main problem encountered with the $\mathrm{Ti} / \mathrm{SnO}_{2}$ anode is its low stability under anodic polarization, which is not the case of the $\mathrm{SnO}_{2}-$ $\mathrm{Sb}_{2} \mathrm{O}_{5}$ coating having an $\mathrm{IrO}_{2}$ interlayer between the Ti substrate [18].

$$
\begin{aligned}
& \mathrm{DSA}+\mathrm{H}_{2} \mathrm{O} \rightarrow \mathrm{DSA}\left({ }^{\circ} \mathrm{OH}\right)+\mathrm{H}^{+}+1 \mathrm{e}^{-} \\
& \mathrm{R}+\mathrm{DSA}\left({ }^{\circ} \mathrm{OH}\right)_{\mathrm{z}} \rightarrow \mathrm{CO}_{2}+\mathrm{zH}^{+}+\mathrm{ze}^{-}+\mathrm{DSA}
\end{aligned}
$$

In a previous paper carried out by our group a film of iridium and tin dioxides doped with antimony oxide $\left(\mathrm{IrO}_{2}-\mathrm{SnO}_{2}-\mathrm{Sb}_{2} \mathrm{O}_{5}\right)$ was deposited onto Ti substrate mesh and plate by the Pechini method [19]. The ternary oxide coating was used for the anodic decolorization of methyl orange (MO) azo dye via reactive oxygen species, such as $\left({ }^{\circ} \mathrm{OH}, \mathrm{H}_{2} \mathrm{O}_{2}\right.$ and $\mathrm{O}_{3}$ ) formed in-situ from water 
oxidation at the $\mathrm{Ti} / \mathrm{IrO}_{2}-\mathrm{SnO}_{2}-\mathrm{Sb}_{2} \mathrm{O}_{5}$ surface. However, in that paper we did not follow the formation of ${ }^{\circ} \mathrm{OH}$ at DSA surface and the electrochemical combustion of organic matter.

The indirect technique for the detection and identification of low concentration of ${ }^{\circ} \mathrm{OH}$ radicals formed by water discharge at the oxide anodes involves trapping of the ${ }^{\circ} \mathrm{OH}$ radical by an addition reaction (spin trap) to produce a more stable radical (spin adduct). A number of ${ }^{\circ} \mathrm{OH}$ radical spin traps are available in the literature but $N, N$-dimethyl- $p$-nitrosoaniline (RNO) has demonstrated to be effective owing to the selective reaction of RNO with ${ }^{\circ} \mathrm{OH}$ radicals, the high rate of the reaction with ${ }^{\circ} \mathrm{OH}$ radicals $\left(k=1.2 \times 10^{-4} \mathrm{M}^{-1} \mathrm{~s}^{-1}\right)$ and the ease of application as one merely observes the bleaching of the sensitive absorption band at $440 \mathrm{~nm}[17,20]$.

The goal of this manuscript is to prepare a film of iridium and tin dioxides doped with antimony $\left(\mathrm{IrO}_{2}-\mathrm{SnO}_{2}-\mathrm{Sb}_{2} \mathrm{O}_{5}\right)$ onto titanium mesh (expanded metal) to produce ${ }^{\circ} \mathrm{OH}$ radicals via water discharge for the electrochemical combustion of indigo textile dye (which resembles a denim laundry industrial wastewater). Bulk electrolyses were then carried out at different mean linear flow velocities and at constant current density using a filter-press flow cell. The integral current efficiency and the energy consumption of electrolysis were estimated. The detection of ${ }^{\circ} \mathrm{OH}$ radicals formed by water discharge at the oxide anode using RNO as spin trap was also examined.

\section{Experimental}

Indigo dye solution was $1 \mathrm{mM}$ indigo textile dye (536 ppm COD) in $0.05 \mathrm{M} \mathrm{NaCl}$ (which resembles a denim laundry industrial wastewater). The resulting solution exhibited a conductivity of $5.78 \mathrm{mS} \mathrm{cm}^{-1}$, and a $\mathrm{pH}$ of 6.3 at $298 \mathrm{~K}$. The solution was deoxygenated with nitrogen for about 10 minutes before each experiment. All the chemicals employed in this work were reactive grade.

\section{Equipment}

A potentiostat-galvanostat model SP-150 coupled to a booster model VMP-3 (20V-10A) both from Bio-Logic ${ }^{T M}$ with EC-Lab ${ }^{\oplus}$ software were used for the electrolysis experiments. The potentials were measured versus a saturated calomel reference electrode (SCE), Bio-Logic model 002056RE-2B. All electrode potentials shown in this work are presented with regard to a standard hydrogen electrode (SHE).

COD analyses were performed using a dry-bath (Lab Line Model 2008), and a Genesys 20 spectrophotometer. Chloride volumetric titrations were confirmed by potentiometric measurements using a silver wire and a SCE, which was inserted in a glassy titration cell. The potential differences between silver wire and SCE were detected by a high impedance multimeter (Agilent-model-34401A). The colour removal was registered using a visible spectrophotometer (Genesys 20).

\section{Microelectrolysis experiments}

A 100- $m$ L Pyrex electrochemical cell, with a three electrode system and nitrogen inlet was used for the construction of the anodic polarization curves. The working electrode was mesh-( $\left(\mathrm{rO}_{2}-\mathrm{SnO}_{2}-\mathrm{Sb}_{2} \mathrm{O}_{5}\right)$ with $1 \mathrm{~cm}^{2}$ geometric area exposed to the electrolyte. The potentials were measured vs. SCE and the counter electrode was a glassy carbon. All the potential measurements shown in this work are presented with regard to standard hydrogen electrode (SHE).

A divided cell made of two compartment quartz cells of $3 \mathrm{~mL}$ capacity each one for the indirect detection of ${ }^{\circ} \mathrm{OH}$ radicals was used. The anode was in the form of plate $\left(1 \mathrm{~cm}^{2}\right)$ and the cathode was a vitreous carbon rod $\left(1 \mathrm{~cm}^{2}\right)$. A home-made salt bridge to connect both semi-cells was employed; this was fabricated with vitreous Pyrex tube of $2 \mathrm{~mm}$ diameter sealed with $\mathrm{Pt}$ at the ends; this bridge was filled with phosphate buffer $(\mathrm{pH} 7.4)$. The quartz cell used as the anodic 
compartment was collocated into the UV-visible spectrophotometer (Perkin Elmer Lambda 35) to follow the bleaching (in-situ) of the yellow color of RNO during electrolysis.

\section{Flow cell experiments}

The flow cell FM01-LC that includes the turbulence promoter type D was used; the detailed description of this cell is depicted elsewhere [21]. In this work the spacer was $0.55 \mathrm{~cm}$ thick. DSA anode was a mesh-( $\left(\mathrm{IO}_{2}-\mathrm{SnO}_{2}-\mathrm{Sb}_{2} \mathrm{O}_{5}\right)$, while platinum coated titanium flat sheet, was used as the cathode. DSA electrode was prepared by Pechini method described below. The platinum coated titanium was provided by De Nora. Details on the FM01-LC cell characteristics are given in Table 1.

Table 1. Mesh-(Ti//IO $\left.{ }_{2}-\mathrm{SnO}_{2}-\mathrm{Sb}_{2} \mathrm{O}_{5}\right)$ electrode dimensions, experimental details of the FMO1-LC electrolyzer.

\begin{tabular}{ll}
\hline Electrode length, $\mathrm{L}$ & $16 \mathrm{~cm}$ \\
Electrode height, $\mathrm{B}$ & $4 \mathrm{~cm}$ \\
Electrode spacing, $\mathrm{S}$ & $0.55 \mathrm{~cm}$ \\
Anode area, $\left(\mathrm{Ti} / \mathrm{IrO}_{2}-\mathrm{SnO}_{2}-\mathrm{Sb}_{2} \mathrm{O}_{5}\right)$ & $112 \mathrm{~cm}^{2}$ \\
Cathode área, $(\mathrm{Ti} / \mathrm{platinized)}$ & $64 \mathrm{~cm}^{2}$ \\
Overall voidage, $\varepsilon\left(\mathrm{Ti} / / \mathrm{IO}_{2}-\mathrm{SnO}_{2}-\mathrm{Sb}_{2} \mathrm{O}_{5}\right)$ & 0.93 \\
Volumetric flow rate, & from 0.1 to $0.4 \mathrm{~L} \mathrm{~min}^{-1}$ \\
\hline Overall voidage is the ratio of the free space in the channel to overall channel volume.
\end{tabular}

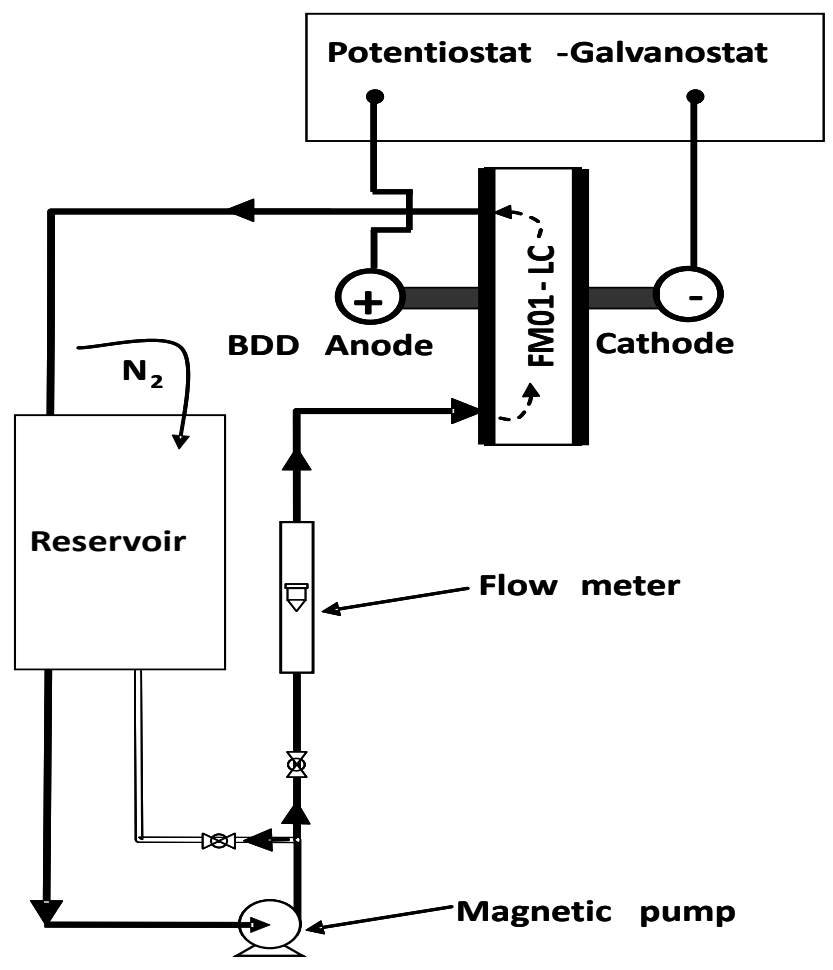

Figure 1. Electrical and flow circuit for the measurement of electrochemical incineration kinetics at FM01-LC electrolyzer.

The undivided FM01-LC cell, with a single electrolyte compartment and the electrolyte flow circuit, is shown in Figure 1. The electrolyte was contained in a $1 \mathrm{~L}$ polycarbonate reservoir. A magnetically coupled pump of $1 / 15$ hp March MFG, model MDX-MT-3 was used; the flow rates were measured by a variable area glass rotameter from Cole Palmer, model F44500. The electrolyte 
circuit was constructed from Master Flex tubing, C-Flex 6424-16, of 0.5 inch diameter. The valves and the three way connectors were made of PVC.

\section{Scanning electron microscopy}

Surface characterization of the metallic coating was performed using a SEM Carl Zeiss DSM 940A microscope. The energy of the primary electrons beam employed was $15 \mathrm{keV}$.

\section{Methodology}

\section{Preparation of the DSA material}

A ternary oxide $\left(\mathrm{IOO}_{2}-\mathrm{SnO}_{2}-\mathrm{Sb}_{2} \mathrm{O}_{5}\right)$ film was deposited onto a Ti plate and mesh to be used in the three electrode cell and in the flow cell (Figure 1) by Pechini method using appropriate molar ratios of the oxide components. The precursor polymer solution was a mixture of citric acid (CA) in ethylene glycol (EG) at $60-70{ }^{\circ} \mathrm{C}$. After total dissolution of the $\mathrm{CA}, \mathrm{H}_{2} \mathrm{IrCl}_{6} \mathrm{xH}_{2} \mathrm{O}, \mathrm{SnCl}_{4}$ and $\mathrm{SbCl}_{3}$ were added to the mixture according to a molar composition of EG:CA:Ir:Sn:Sb as 16:0.12:0.0296:0.0296:0.0004, maintaining the temperature at $60-70{ }^{\circ} \mathrm{C}$ for $30 \mathrm{~min}$. This mixture was then applied with a brush to both sides of the pre-treated Ti support. After the application of the coating, the electrode was heated at $100{ }^{\circ} \mathrm{C}$ for $5 \mathrm{~min}$ in a furnace in order to induce the polymerization of the precursor. This procedure was repeated eight times. After the final coating, the electrodes were maintained at $550{ }^{\circ} \mathrm{C}$ for $1 \mathrm{~h}$ in order to calcinate the polymer and form the ternary oxide $\left(\mathrm{IrO}_{2}-\mathrm{SnO}_{2}-\mathrm{Sb}_{2} \mathrm{O}_{5}\right)$; XRD analysis confirmed at such at temperature these oxide phases are obtained [22]. The temperature did not exceed $600{ }^{\circ} \mathrm{C}$ to avoid the formation of $\mathrm{TiO}_{2}$ that markedly reduces the electrocatalytic properties of the $\mathrm{Ti} / \mathrm{IrO}_{2}-\mathrm{SnO}_{2}-\mathrm{Sb}_{2} \mathrm{O}_{5}$ coating due to passivation [23].

\section{Microelectrolysis tests}

Anodic polarization curves to determine the limits of potential and current density where the media is oxidized at $\mathrm{Ti} / \mathrm{IrO}_{2}-\mathrm{SnO}_{2}-\mathrm{Sb}_{2} \mathrm{O}_{5}$ electrode were performed. These studies were carried out

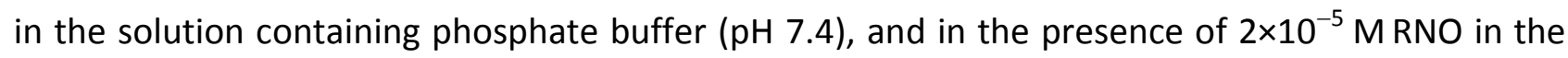
same buffer at room temperature $(298 \mathrm{~K})$. Anodic potential limit of $1.6 \mathrm{~V}$ vs. SHE was applied from open circuit potential (OCP) $(0.82 \mathrm{~V}$ vs. SHE) using the linear sweep voltammetry technique at $50 \mathrm{mV} \mathrm{s}^{-1}$. Based on these polarization curves the detection of hydroxyl radicals was performed.

Detection of hydroxyl radicals

In this paper RNO was used as spin trap for the detection of low concentration of ${ }^{\circ} \mathrm{OH}$ radicals formed by water discharge at the $\mathrm{Ti} / \mathrm{IrO}_{2}-\mathrm{SnO}_{2}-\mathrm{Sb}_{2} \mathrm{O}_{5}$ electrode and the bleaching of the yellow colour was measured during electrolysis [17]. RNO traps the ${ }^{\circ} \mathrm{OH}$ radical by an addition reaction to produce a more stable radical (spin adduct), Eq. (3) [17].

$$
\mathrm{RNO}+{ }^{\cdot} \mathrm{OH} \rightarrow \underset{\text { RNO }}{\mathrm{RN}^{\cdot}}
$$

\section{(spin trap) (spin adduct)}

It is important to mention that $\mathrm{RNO}$ is electrochemical inactive at $\mathrm{Pt}, \mathrm{SnO}_{2}$ and $\mathrm{IrO}_{2}$ anodes $[17,20]$. A divided cell for the indirect detection of ${ }^{\circ} \mathrm{OH}$ radicals was used (see microelectrolysis experiments section). Anodes screening tests were carried out in phosphate buffer $(\mathrm{pH}=7.4)$ containing $2 \times 10^{-5} \mathrm{M}$ RNO. Galvanostatic electrolyses at current densities of 5,7 and $10 \mathrm{~mA} \mathrm{~cm}^{-2}$ applied to the $\mathrm{Ti} / \mathrm{IrO}_{2}-\mathrm{SnO}_{2}-\mathrm{Sb}_{2} \mathrm{O}_{5}$ electrode were performed; at the same time the bleaching 
(in-situ) of the yellow color of RNO during electrolysis was followed. The same tests were performed using Pt plate $\left(1 \mathrm{~cm}^{2}\right)$ as anode for which the surface ${ }^{\circ} \mathrm{OH}$ radical concentration is almost zero [17].

Electrochemical incineration in the filter-press flow cell.

Electrochemical incinerations of indigo were carried out in the FM01-LC cell equipped with mesh-( $\left.\mathrm{Ti} / \mathrm{IrO}_{2}-\mathrm{SnO}_{2}-\mathrm{Sb}_{2} \mathrm{O}_{5}\right)$ at current density of $7 \mathrm{~mA} \mathrm{~cm}{ }^{-2}$, value determined from microelectrolysis studies, at different volumetric flow rates between $0.1-0.4 \mathrm{~L} \mathrm{min.}^{-1}$.

Incineration evolution was estimated by COD analysis of samples taken at different times. The COD values were determined by closed reflux dichromate titration method [24]. It is important to mention that estimating residual organic matter by COD analysis allowed eliminating any interference from chloride species. For this method, an excess of $\mathrm{HgSO}_{4}$ was added and $\mathrm{Ag}_{2} \mathrm{SO}_{4}$ in the digestion and catalyst solutions, respectively, with the purpose of eliminating possible interferences from chloride species during the estimation of the residual organic matter from COD analysis [12].

The chloride concentration was evaluated by volumetric titration using a $0.5 \mathrm{M} \mathrm{AgNO}_{3}$, confirmed by potentiometric measurements [12]. In addition, the color removal was determined by the decrease in absorbance at $639 \mathrm{~nm}$, during electrolyzes.

\section{Results and Discussion}

\section{Characterization of DSA}

Figure 2 presents typical scanning electron micrographs for freshly prepared electrode $\mathrm{Ti} / \mathrm{IrO}_{2}-$ $\mathrm{SnO}_{2}-\mathrm{Sb}_{2} \mathrm{O}_{5}$. The surface morphology of the layer is characterized by the presence of crackers and plates. The presence of plates on the surface is probably due to the drastic heat treatment to which the sampled was submitted, that promoted the rapid exit of $\mathrm{CO}_{2}$ gas originated from the decomposition of the organic polymer. EDX analyses focused on several plate structures show heterogeneous atomic percentage ratio of Sn and Ir (between 1.6 to 2.74), indicating that Sn segregates from other oxide to form a Sn rich deposit. Moreover, antimony was randomly detected along the electrode, showing that $\mathrm{Sb}$ is not homogeneously distributed along the electrode surface owing to its low content.

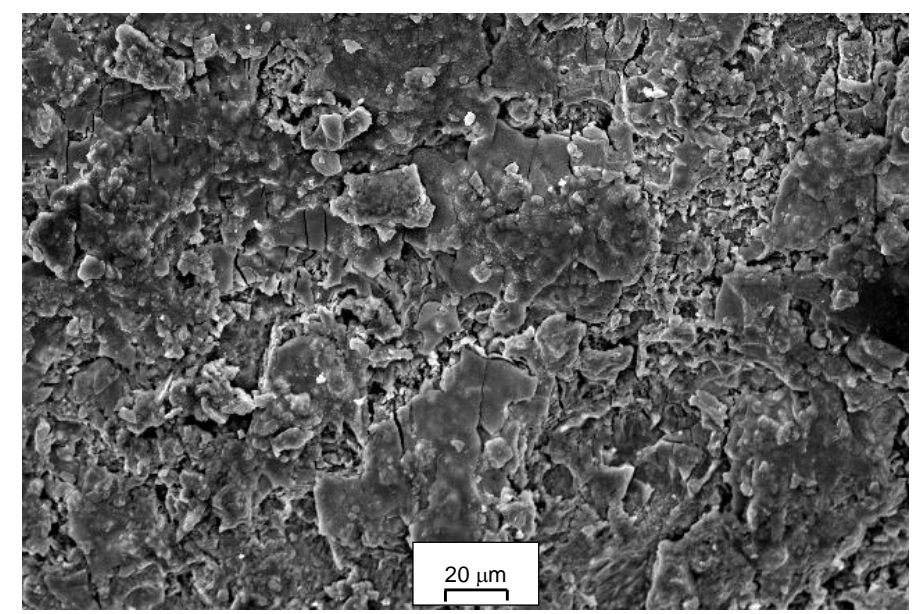

Figure 2. SEM images of $\mathrm{Ti} / \mathrm{IrO} \mathrm{O}_{2}-\mathrm{SnO}_{2}-\mathrm{Sb}_{2} \mathrm{O}_{5}$.

Figure 3 shows typical linear sweep voltammetries obtained on $\mathrm{Ti} / \mathrm{IrO}_{2}-\mathrm{SnO}_{2}-\mathrm{Sb}_{2} \mathrm{O}_{5}$ electrode in the solution containing phosphate buffer ( $\mathrm{pH} 7.4$ ), and in the presence of $2 \times 10^{-5} \mathrm{MRNO}$ in the 
same buffer where no differences were detected. The fact that no changes were detected in both electrolytic solutions suggests the oxidation of water which is found in excess. Tafel slope performed on $\mathrm{Ti} / \mathrm{IrO}_{2}-\mathrm{SnO}_{2}-\mathrm{Sb}_{2} \mathrm{O}_{5}$ from these curves (see inset), gives value of $190 \mathrm{mV} \mathrm{dec}{ }^{-1}$, which is different to that reported for $\mathrm{Ti} / \mathrm{IrO}_{2} / \mathrm{SnO}_{2}-\mathrm{Sb}_{2} \mathrm{O}_{5}$ and $\mathrm{Ti} / \mathrm{Pt} / \mathrm{SnO}_{2}-\mathrm{Sb}_{2} \mathrm{O}_{4}, 120$ and $204 \mathrm{mV} \mathrm{dec}{ }^{-1}$ obtained at $298 \mathrm{~K}$, respectively $[12,25]$; this difference is associated with the electrode composition and by the method of preparation.

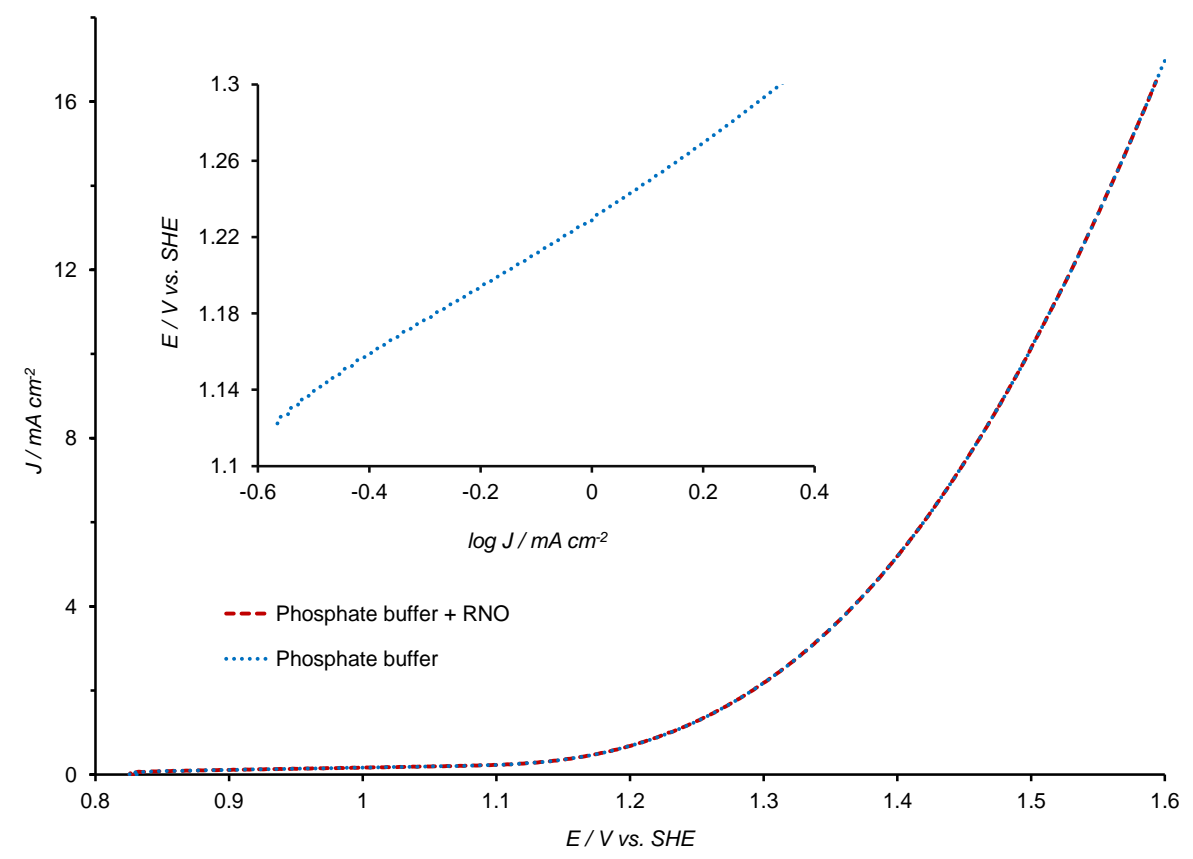

Figure 3. Typical linear sweep voltammetries on $\mathrm{Ti} / \mathrm{IrO}_{2}-\mathrm{SnO}_{2}-\mathrm{Sb}_{2} \mathrm{O}_{5}$ anode.

Electrolyte: phosphate buffer ( $\mathrm{pH}$ 7.4), and phosphate buffer $+2 \times 10^{-5} \mathrm{MRNO}$. The scan rate was $50 \mathrm{mV} \mathrm{s}^{-1}$. The inset shows the Tafel plot for J-E curves for phosphate buffer. A $=1 \mathrm{~cm}^{2} . \mathrm{T}=298 \mathrm{~K}$.
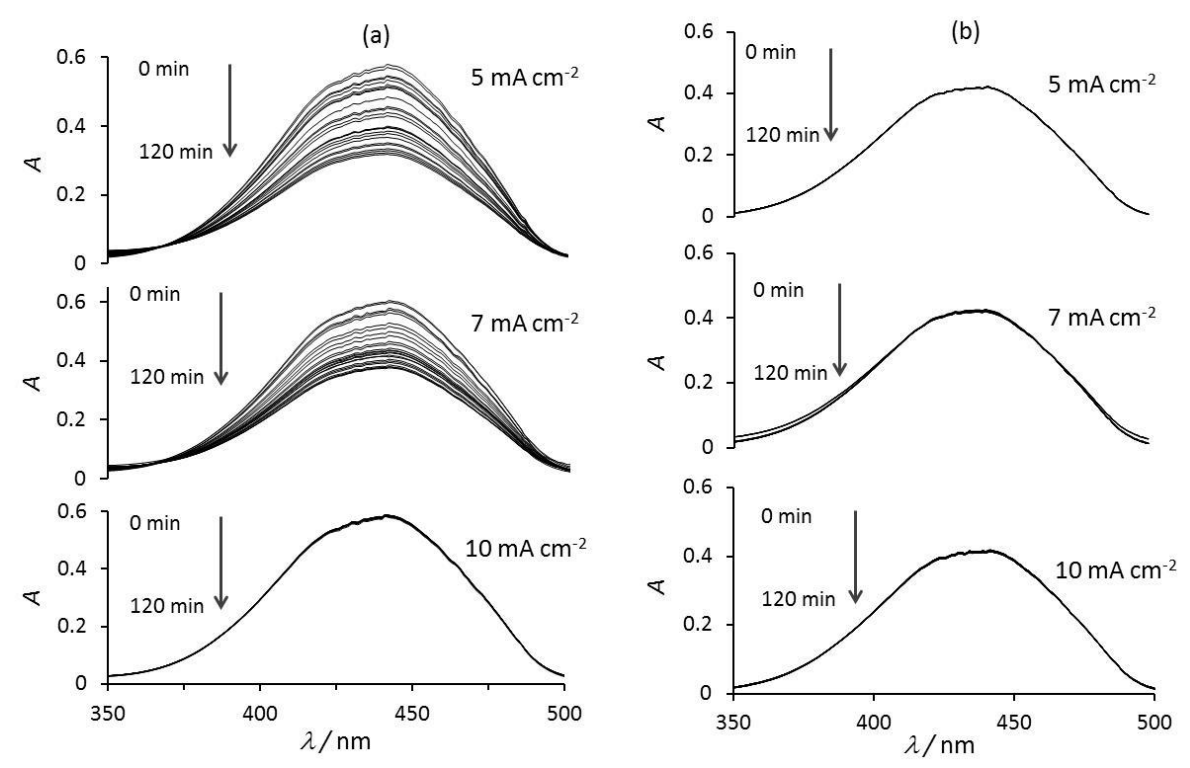

Figure 4. Absorbance spectra of RNO $\left(2 \times 10^{-5} \mathrm{M}\right)$ in phosphate buffer $(\mathrm{pH}=7.4)$ obtained at 5 min intervals during galvanostatic electrolyses with $\mathrm{Ti} / \mathrm{IrO}_{2}-\mathrm{SnO}_{2}-\mathrm{Sb}_{2} \mathrm{O}_{5}(\mathrm{a})$ and $\mathrm{Pt}(\boldsymbol{b})$ anodes. $\mathrm{A}=1 \mathrm{~cm}^{2} . \mathrm{T}=298 \mathrm{~K}$.

For screening tests of anodes we used RNO as spin trap of ${ }^{\circ} \mathrm{OH}$ radicals. Figure 4 shows the absorption spectrum of aqueous solution $\left(2 \times 10^{-5} \mathrm{M}\right.$ RNO) in phosphate buffer at $\mathrm{pH} 7.4$ during 
galvanostatic electrolysis at 5,7 and $10 \mathrm{~mA} \mathrm{~cm}{ }^{-2}$ with $\mathrm{Ti} / \mathrm{IrO}_{2}-\mathrm{SnO}_{2}-\mathrm{Sb}_{2} \mathrm{O}_{5}$ and $\mathrm{Pt}$ electrode. With $\mathrm{Pt}$ anode, there is no decrease in absorbance at $440 \mathrm{~nm}$, at the three current densities, contrary to the $\mathrm{Ti} / \mathrm{IrO}_{2}-\mathrm{SnO}_{2}-\mathrm{Sb}_{2} \mathrm{O}_{5}$ anode for which there is a rapid decrease in the absorbance at 5 and $7 \mathrm{~mA} \mathrm{~cm}{ }^{-2}$. These results show that there is accumulation of ${ }^{\circ} \mathrm{OH}$ radicals at the $\mathrm{Ti} / \mathrm{IrO}_{2}-\mathrm{SnO}_{2}-\mathrm{Sb}_{2} \mathrm{O}_{5}$ electrode surface contrary to $\mathrm{Pt}$ anode for which the surface ${ }^{\circ} \mathrm{OH}$ radical is almost zero. The fact that the $\mathrm{Ti} / \mathrm{IrO}_{2}-\mathrm{SnO}_{2}-\mathrm{Sb}_{2} \mathrm{O}_{5}$ anode at $10 \mathrm{~mA} \mathrm{~cm}{ }^{-2}$ behaves similar to that $\mathrm{Pt}$ suggests that at such current density the accumulation of ${ }^{\circ} \mathrm{OH}$ radicals is zero and the oxygen evolution reaction starts to appear. Therefore, according to the proposed reactions (Eqs. (1) and (2)) $[14,17]$ the $\mathrm{Ti}^{\prime} / \mathrm{IO}_{2^{-}}$ $\mathrm{SnO}_{2}-\mathrm{Sb}_{2} \mathrm{O}_{5}$ will favor complete combustion of indigo textile dye at 5 and $7 \mathrm{~mA} \mathrm{~cm}^{-2}$.

\section{Electrochemical incineration of indigo textile dye in the FM01-LC using DSA electrode}

Figures 5 (a) and (b) show the normalized color (detected at $\lambda=639 \mathrm{~nm}$ ) and COD results obtained from experiments performed at constant current density $\left(7 \mathrm{~mA} \mathrm{~cm}{ }^{-2}\right)$ and variable volumetric flow rates. In these figures, the normalized color decreases faster than COD with the electrolysis time at different volumetric flow rates. COD kinetic was lower than that obtained for color decay owing to the slower combustion of by-products. However, color and COD depletion do not show marked improvement at the elevated volumetric flow rates.

Given that the presence of chloride ions (i.e., $0.05 \mathrm{M}$ in this study) is relevant due to the possible formation of active chlorine by oxidation at $\mathrm{Ti} / \mathrm{IrO}_{2}-\mathrm{SnO}_{2}-\mathrm{Sb}_{2} \mathrm{O}_{5}$, the chloride consumption at the end of the electrolysis was measured (Figure 6), giving an average conversion between $15-40 \%$. This value did not show a marked dependence with hydrodynamics. This indicates that, despite the predominant role of $\mathrm{Ti} / \mathrm{IrO}_{2}-\mathrm{SnO}_{2}-\mathrm{Sb}_{2} \mathrm{O}_{5}\left({ }^{\circ} \mathrm{OH}\right)$ as oxidant species, indigo and/or its byproducts can be simultaneously destroyed by other oxidants such as dissolved chlorine gas, hypochlorous acid $(\mathrm{HClO})$ and hypochlorite ion $\left(\mathrm{ClO}^{-}\right)$, as well as chlorate and perchlorate ions formed upon electro-oxidation with $\mathrm{Ti} / \mathrm{IrO}_{2}-\mathrm{SnO}_{2}-\mathrm{Sb}_{2} \mathrm{O}_{5}$ electrode.

The complete combustion obtained here confirms that the ${ }^{\circ} \mathrm{OH}$ radical, in addition to the other oxidants, are responsible for the oxidation of indigo, which does not occur on platinum electrodes, where the oxidation of indigo in chloride medium achieved $60 \%$ in terms of COD [7]. The results obtained here are in agreement with other articles carried out by our group, where we achieved the complete combustion of indigo mediated by $\mathrm{OH}^{\bullet}$ and active chlorine (produced on BDD in the same filter-press flow cell) $[12,13]$.

The fact that hydrodynamics does not improve indigo oxidation and color removal may be associated with a complex mechanism of indigo degradation. HPLC studies would be helpful in the identification of possible indigo oxidation by-products; however, these were beyond the scope of the present work. It is important to point out that all of the electrolyses presented herein were carried out in the undivided FM01-LC cell, for which reason the degradation of indigo may also involve reactions at the cathode $(\mathrm{Ti} / \mathrm{Pt})$.

With the data obtained from COD for all of the electrolyses at their respective volumetric flow rates, integral current efficiency and energy consumption were analyzed as a function of percentage of indigo oxidation, for electrolyses performed at $7 \mathrm{~mA} \mathrm{~cm}{ }^{-2}$, Figure 7 (a)-(b). The estimation of integral current efficiency and energy consumption were determined using Equations (4) and (5) [12]: 

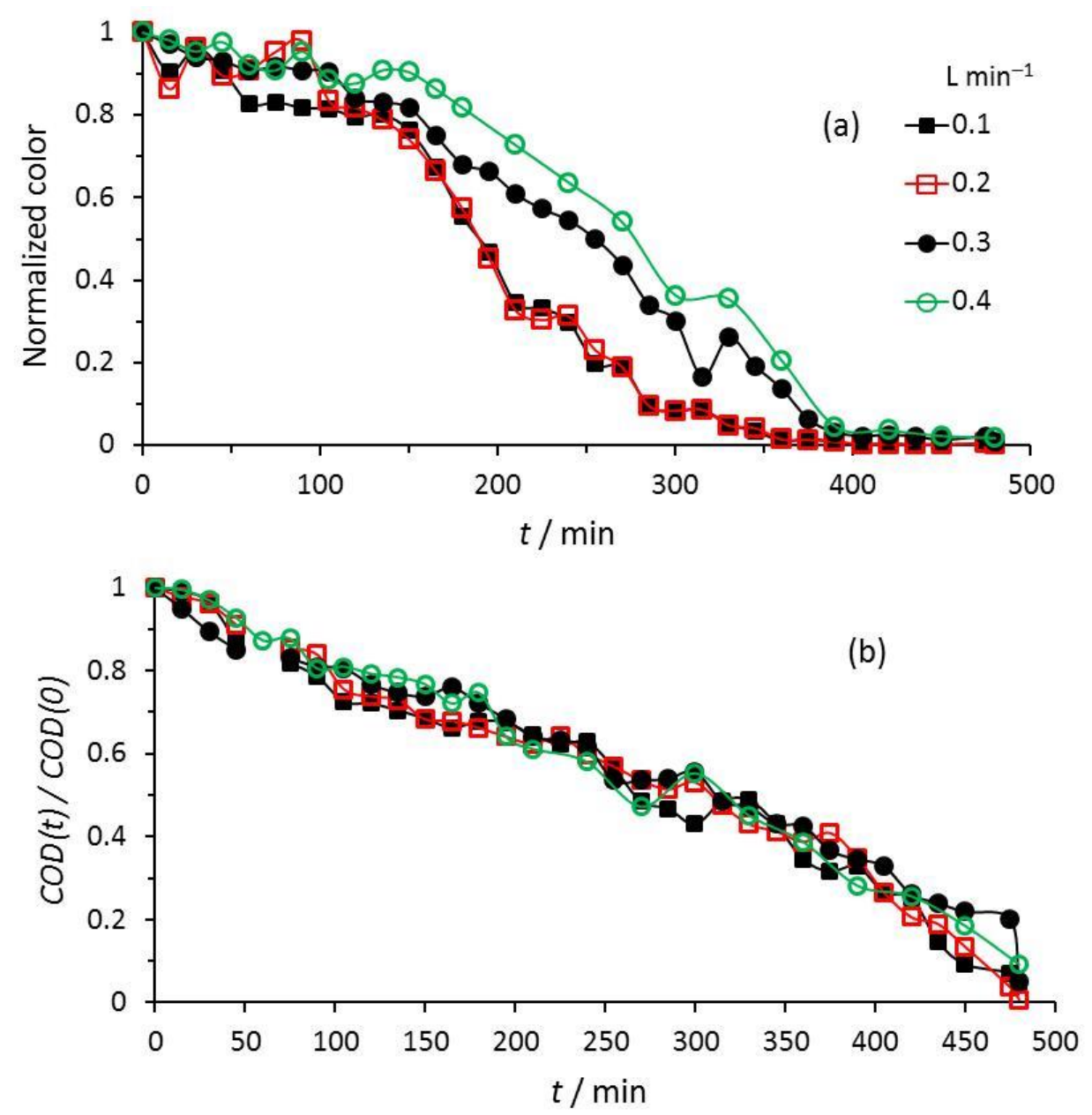

Figure 5. Normalized color $(\lambda=639 \mathrm{~nm})(\boldsymbol{a})$ and $\operatorname{COD}(\boldsymbol{b})$ decay during the electrolyses of indigo on $\left(\mathrm{Ti} / \mathrm{IrO}_{2}-\mathrm{SnO}_{2}-\mathrm{Sb}_{2} \mathrm{O}_{5}\right)$ in the FM01-LC electrolyzer. Electrolyte: $1 \mathrm{mM}$ indigo in $0.05 \mathrm{M} \mathrm{NaCl}$; this composition resembles a denim laundry wastewater. $A=112 \mathrm{~cm}^{2}, \mathrm{j}=7 \mathrm{~mA} \mathrm{~cm} \mathrm{~cm}^{-2}, \mathrm{~T}=298 \mathrm{~K}$. Volumetric flow rates are shown in the figure.

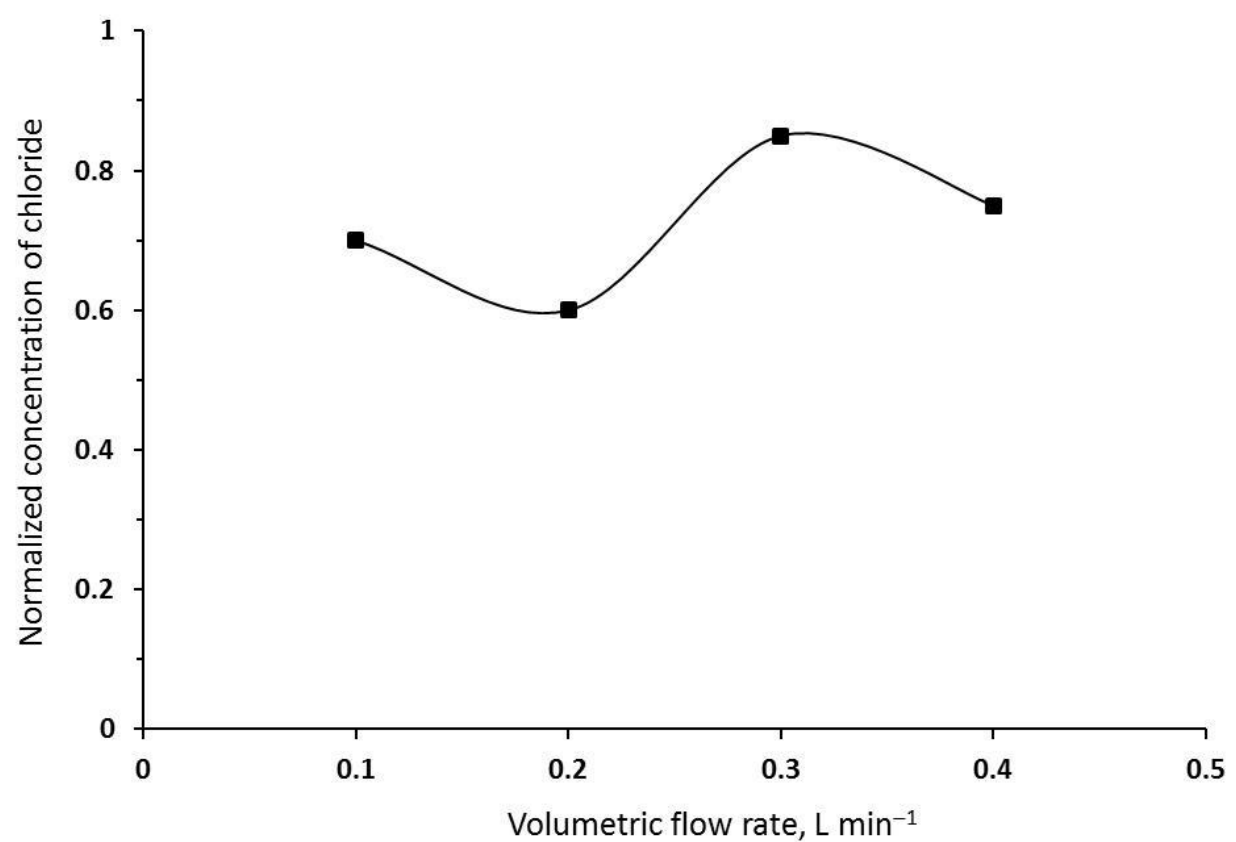

Figure 6. Normalized concentration of chloride versus volumetric flow rates evaluated at the end of the electrolyses similar to those from Fig. 5(b). Electrolyte: $1 \mathrm{mM}$ indigo in $0.05 \mathrm{M} \mathrm{NaCl}$. A $=112 \mathrm{~cm}^{2}$, $\mathrm{j}=7 \mathrm{~mA} \mathrm{~cm}^{-2}, \mathrm{~T}=298 \mathrm{~K}$. Volumetric flow rates are shown in the figure. 


$$
\begin{aligned}
& \varphi=\frac{4 F V[\operatorname{COD}(0)-\operatorname{COD}(t)]}{1 t} \\
& E_{\mathrm{c}}=\frac{4 F E_{\mathrm{cell}}}{\varphi V_{\mathrm{m}}} \frac{1}{3.6}
\end{aligned}
$$

where $F$ is the Faraday constant, $96485 \mathrm{C} \mathrm{mol}^{-1}, V$ is the solution volume $\left(\mathrm{cm}^{-3}\right), \operatorname{COD}(0)$ and $\operatorname{COD}(t)$ are the chemical oxygen demand initially and at time $(t)$ of the electrolysis, in mol $\mathrm{cm}^{-3}, l$ is the applied current, in $A, t$ is the time of electrolysis $(\mathrm{s}), E_{\text {cell }}$ is the cell potential in $\mathrm{V}$, and $V_{\mathrm{m}}$ is the molar volume in $\mathrm{cm}^{3} \mathrm{~mol}^{-1}$. The value of 3.6 is a correction factor which converts $E_{\mathrm{c}}$ to units of $\mathrm{KWh} \mathrm{m}^{-3}$.

Figure 7(a) shows that current efficiency surpasses $100 \%$ (theoretical value) at volumetric flow rates of 0.1 and $0.3 \mathrm{~L} \mathrm{~min}^{-1}$, suggesting those indigo oxidation by-products and/or the processes taking place at the cathode enhance the degradation of indigo. A similar behavior was obtained in a previous communication carried out by our group [12], during indigo mineralization process in the same filter-press reactor. On the other hand, for the volumetric flow rates of 0.2 and $0.4 \mathrm{~L} \mathrm{~min}^{-1}$, the current efficiencies were lower than that obtained for 0.1 and $0.3 \mathrm{~L} \mathrm{~min} \mathrm{~m}^{-1}$. It is important to remark that at the end of the electrolyses the current efficiency where $80 \%$ for all volumetric flow rates studied, and there are no marked effects of the hydrodynamics on current efficiency in the set of electrolyses studied herein.

The analysis of Figure 7(b) shows that the energy consumption is not strongly influenced by hydrodynamics at $0.2-0.4 \mathrm{~L} \mathrm{~min}^{-1}$. It is important to emphasize that the energy consumption is at least four times lower than those obtained in a previous paper, carried out by our group using the FM01-LC electrolyzer equipped with BDD electrodes in the same indigo solution [12]. This savings in energy consumption is due to the lower electrode polarization obtained using DSA (1.2 V) than the obtained on BDD (2.4 V), diminishing cell potential.
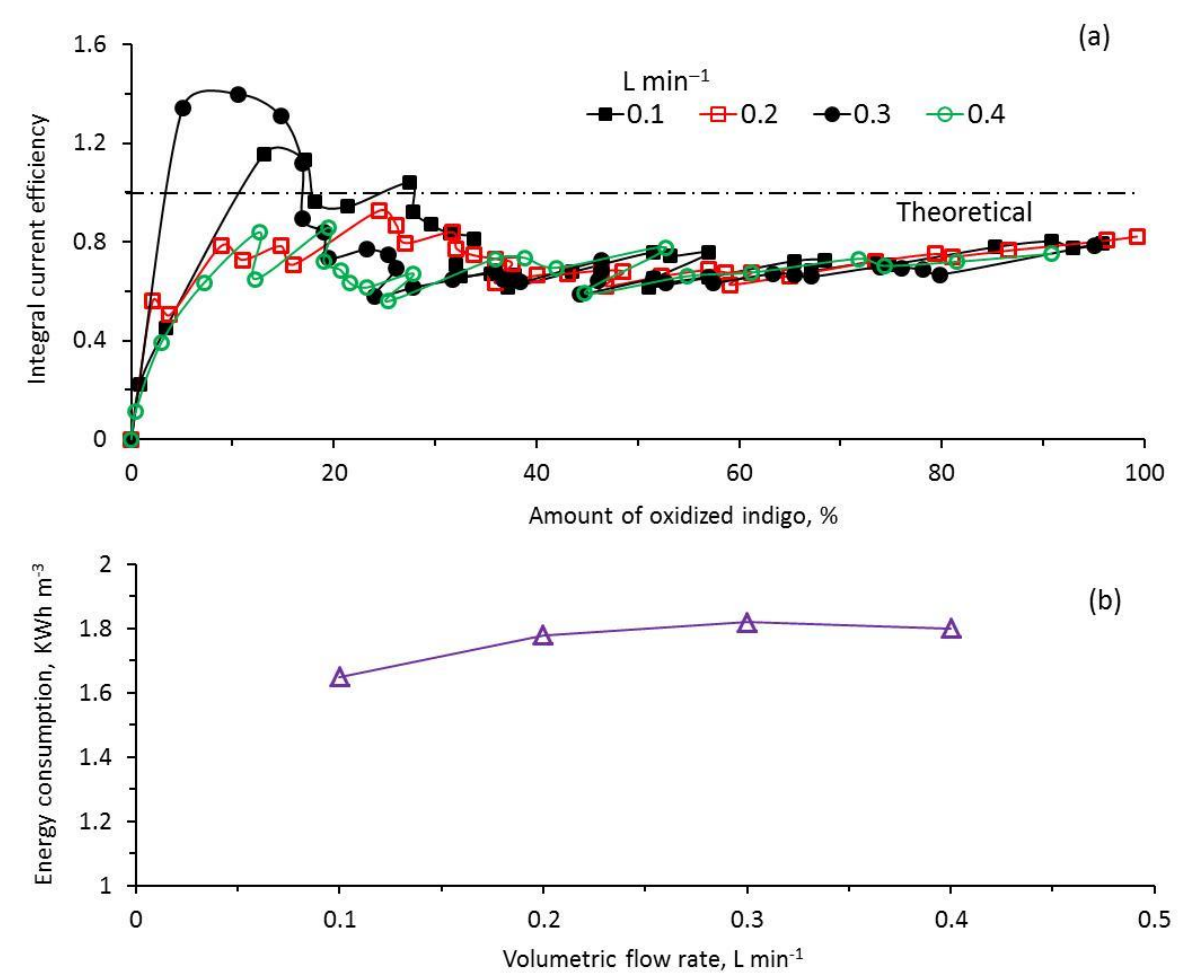

Figure 7. (a) Integral current efficiency versus percentage of oxidized indigo in the FM01-LC electrolyzer, evaluated from the electrolyses similar to those from Fig. 5(b). (b) Energy consumption versus volumetric flow rate evaluated at $88 \%$ of degradation from the electrolyses similar to those from Fig. 5(b). 
The study presented here indicates that, despite the predominant role of $\mathrm{Ti} / \mathrm{IrO}_{2}-\mathrm{SnO}_{2}-\mathrm{Sb}_{2} \mathrm{O}_{5}\left({ }^{\circ} \mathrm{OH}\right)$ as oxidant species, indigo and/or its by-products can be simultaneously destroyed by other oxidants such as dissolved chlorine gas, hypochlorous acid ( $\mathrm{HClO}$ ) and hypochlorite ion $\left(\mathrm{ClO}^{-}\right)$, as well as chlorate and perchlorate ions formed upon electro-oxidation with $\mathrm{Ti} / \mathrm{IrO}_{2}-\mathrm{SnO}_{2}-\mathrm{Sb}_{2} \mathrm{O}_{5}$ electrode.

\section{Conclusions}

The detection of ${ }^{\circ} \mathrm{OH}$ radicals formed by water discharge at $\mathrm{Ti}^{\prime} / \mathrm{IrO}_{2}-\mathrm{SnO}_{2}-\mathrm{Sb}_{2} \mathrm{O}_{5}$ using $\mathrm{N}, \mathrm{N}$-dimethyl-p-nitrosoaniline (RNO) as a spin trap showed that exits an accumulation of ${ }^{\circ} \mathrm{OH}$ radical at $\mathrm{Ti} / \mathrm{IrO}_{2}-\mathrm{SnO}_{2}-\mathrm{Sb}_{2} \mathrm{O}_{5}$ surface. Therefore, the $\mathrm{Ti} / \mathrm{IrO}_{2}-\mathrm{SnO}_{2}-\mathrm{Sb}_{2} \mathrm{O}_{5}$ anode favors complete combustion of indigo by bulk electrolysis.

The galvanostatic tests using $\mathrm{RNO}$ as spin trap of ${ }^{\circ} \mathrm{OH}$ radicals confirmed that $\mathrm{Ti} / \mathrm{IrO}_{2}-\mathrm{SnO}_{2}-\mathrm{Sb}_{2} \mathrm{O}_{5}$ will favor the hydroxyl radical formation at current densities between 5 and $7 \mathrm{~mA} \mathrm{~cm}{ }^{-2}$, while at current density of $10 \mathrm{~mA} \mathrm{~cm}{ }^{-2}$ the oxygen evolution reaction occurs.

Electrolyses in a FM01-LC flow cell indicates, that despite the predominant role of $\mathrm{Ti} / \mathrm{IrO}_{2}-\mathrm{SnO}_{2}-\mathrm{Sb}_{2} \mathrm{O}_{5}\left({ }^{\circ} \mathrm{OH}\right)$ as oxidant species, indigo and/or its by-products can be simultaneously destroyed by other oxidants such as dissolved chlorine gas, hypochlorous acid $(\mathrm{HClO})$ and hypochlorite ion $\left(\mathrm{ClO}^{-}\right)$, as well as chlorate and perchlorate ions formed upon electro-oxidation with $\mathrm{Ti} / \mathrm{IrO}_{2}-\mathrm{SnO}_{2}-\mathrm{Sb}_{2} \mathrm{O}_{5}$ electrode.

The mineralization of indigo carried out at $0.2 \mathrm{~L} \mathrm{~min}^{-1}$ and $7 \mathrm{~mA} \mathrm{~cm}{ }^{-2}$ achieved values of $100 \%$, with current efficiencies $80 \%$, and energy consumption of $1.78 \mathrm{KWh} \mathrm{m}^{-3}$. The FM01-LC equipped with mesh-( $\left.\mathrm{Ti} / \mathrm{IrO}_{2}-\mathrm{SnO}_{2}-\mathrm{Sb}_{2} \mathrm{O}_{5}\right)$ improves space-time yield, allowing better interaction between mesh- $\left(\mathrm{Ti} / \mathrm{IrO}_{2}-\mathrm{SnO}_{2}-\mathrm{Sb}_{2} \mathrm{O}_{5}\right)\left({ }^{\circ} \mathrm{OH}\right)$ and organics, a phenomenon that increases organic mineralization efficiency.

In this manner, the complete mineralization of indigo with high current efficiency, obtained in this work is a notable improvement over those reported in the literature by using other DSA electrode. Additionally, the performance of the FM01-LC electrolyzer equipped with mesh$\left(\mathrm{Ti} / \mathrm{IrO}_{2}-\mathrm{SnO}_{2}-\mathrm{Sb}_{2} \mathrm{O}_{5}\right)$ electrodes, demonstrate the convenience of using this electrochemical reactor as a pre-pilot cell for other water samples containing recalcitrant organic matter.

Acknowledgements: María I. León and Zaira G. Aguilar thank CONACYT for the given grant. Authors are grateful to CONACYT and CONCYTEG for the economic support via the project FOMIX GTO-2012-C04-195057. Authors also acknowledge Universidad de Guanajuato for the financial support.

\section{References}

[1] Y. Wong, J. Yu, Water Research 33 (1999) 3512-3520.

[2] P. Cañizares, F. Martínez, C. Jiménez, J. Lobato, M. A. Rodrigo, Environmental Science \& Technology 40 (2006) 6418-6424.

[3] N. Mohan, N. Balasubramanian, V. Subramanian, Chemical Engineering \& Technology 24 (2001) 749-753.

[4] M. Faouzi, P. Cañizares, A. Gadri, J. Lobato, B. Nasr, R. Paz, M. A. Rodrigo, C. Sáez, Electrochimica Acta 52 (2006) 325-331.

[5] X. Chen, G. Chen, Separation and Purification Technology 48 (2006) 45-49.

[6] X. Chen, F. Gao, G. Chen, Journal of Applied Electrochemistry 35 (2005) 185-191.

[7] D. Dogan, H. J. Turkdemir, Journal of Chemical Technology and Biotechnology 80 (2005) 916-923. 
[8] D. Rajkumar, B. J. Song, J. G. Kim, Dyes and Pigments 72 (2007) 1-7.

[9] A. M. Faouzi, B. Nasr, G. Abbdellati, Dyes and Pigments 73 (2007) 86-89.

[10] P. Cañizares, A. Gadri, J. Lobato, B. Nasr, M. A. Rodrigo, C. Saez, Industrial \& Engineering Chemistry Research 45 (2006) 3468-3473.

[11] F. H. Oliveira, M. E. Osugi, F. M. M. Paschoal, D. Profeti, P. Olivi, M. V. B. Zanoni, Journal of Applied Electrochemistry 37 (2007) 583-592.

[12] E. Butrón, M. E. Juárez, M. Solis, M. Teutli, I. González and J. L. Nava, Electrochimica Acta 52 (2007) 6888-6894.

[13] J. L. Nava, I. Sirés, E. Brillas. Environmental Science and Pollution Research 21 (2014) 84858492.

[14] C. L. P. S. Zanta, P. A. Michaud, C. Comninellis, A. R. de Andrade, J. F. C. Boodts, Journal of Applied Electrochemistry 33 (2003) 1211-1215.

[15] M. Tian, L. Bakovic, A. Chen, Electrochimica Acta 52 (2007) 6517-6524.

[16] N. Matyasovszky, M. Tian, A. Chen, Journal of Physical Chemistry A 113 (2009) 9348-9353.

[17] C. Comninellis, Electrochimica Acta 39 (1994) 1857-1862.

[18] B. Correa-Lozano, Ch. Comninellis, A. De Battisti, Journal of Applied Electrochemistry 27 (1997) 970-974.

[19] R. Chaiyont, C. Badoe, C. Ponce de León, J.L. Nava, J. Recio, I. Sirés, P. Herrasti, F.C. Walsh, Chemical Engineering \& Technology 36 (2013) 123-129.

[20] J. Muff, L. R. Bennedsen, E. G. Søgaard, Journal of Applied Electrochemistry 41 (2011) 599607.

[21] C. J. Brown, F. C. Walsh, D. Pletcher, Transactions of the Institute of Chemical Engineers, 73A, (1994) 196-205.

[22] X. Qin, F. Gao, G. Chen, Journal of Applied Electrochemistry 40 (2010) 1797-1805.

[23] M. P. Pechini, N. Adams, US Patent 3 3,330,697 (1967).

[24] APHA, AWWA, WPCF, Standard methods for the examination of water and wastewater, New York, USA, 1995.

[25] D. Santos, A. Lopes, M. J. Pacheco, A. Gomes, L. Ciríaco, Journal of the Electrochemical Society 161 (2014) H564-H572.

(C) 2014 by the authors; licensee IAPC, Zagreb, Croatia. This article is an open-access article distributed under the terms and conditions of the Creative Commons Attribution license (http://creativecommons.org/licenses/by/3.0/) (cc) Er 